\title{
EFFECT OF KHAT ON INTRAUTERINE FETAL GROWTH AND ON THE DEVELOPMENT OF THE FETAL SKELETON IN ALBINO RATS
}

\author{
Naglaa Aly Ibrahim \\ Department of Anatomy, Faculty of Medicine, Cairo University
}

\section{INTRODUCTION}

Khat (Catha Edulis) is a plant that grows primarily in Ethiopia, Kenya and Yemen (Zein, 1983). The alkaloid cathinone, a phenylalkylamine namely (-)-alphaaminopropiophenone, is regarded as the main active component of khat (Sxendrei, 1980; Kalix, 1991). This substance is metabolized in the body to nor-ephedrine and nor-pseudo-ephedrine which are readily excreted in urine (Wilder et al., 1994). Moreover, nor-pscudo-ephedrine was detected in mother's milk and in the urine of suckling infants of Khat-chewing lactating women (Kristianson et al., 1987).

Cathinone produces amphetamine-like stimulation of the central nervous system in man, thus it induces a state of euphoria, increased intellectual efficiency, alertness and subjective well being (Kalix, 1988; Nencini and Ahmed, 1989; Brenneisen et al., 1990; Kalix, 1990 \& 1992; Wilder et al., 1994). A large number of people in East Africa and Southern Arabia are used to chew the khat leaves because of its pleasurable and stimulating effects. Due to its habit-forming property, khat has been classificd as a "Substance of Abuse" by the World Health Organization (Al-Meshal et al., 1991). Moreover, Kalix (1991) added that a derivative of cathinone (d-nor-pseudo-ephedrine) was commonly used in clinical practice as antideprassant and as an appetite suppressant - as it has the same well known anorexigenic effect of amphetamine.

Cathinone was found to have the same mechanism of action of amphetamine (Schechter, 1990). It is thought to be a dopaminergic drug either through the release of physiological catecholamine from presynaptic storage sites (Brenneisen et al., 
1990; Kalix, 1991) or through the inhibition of mono-amine oxidase (Calcagnetti and Schechter, 1992).

A large number of medical problems have been reported in Khat chewers (Mekasha, 1983; Soufi et al., 1991; Kassie et al., 2001). The toxicological potential of Khat on various organs was further confirmed by many studies on experimental animals treated with Khat extract (Saleh et al., 1988; Islam et al., 1990; Hanaa et al., 1994; Zaghloul and Nada, 1994). Only few reports dealt with its effect on the growth of the offspring of Khat chewing mothers (Abdul Ghani et al., 1987; Jansson et al, 1988; Eriksson et al., 1991; Gamal, 1996). Its possible teratogenic effect, especially on the skeletal system, attracted little attention in the previous studies (Islam et al., 1994).

The present study was undertaken to investigate the effect of khat administration to pregnant rats on the viability and growth of the fetuses with a special focus on its possible teratogenic effect on the fetal skeleton.

\section{MATERIALS AND METHODS}

The Khat extract was obtained by treatment of the chewable khat leaves with sodium carbonate then extracted by cthanol according to the method of Klein (1979). The solvent was completely evaporated at low pressure and an aqueous suspension of the dried extract was used in this study. The cxtract of $100 \mathrm{gm}$ of chewable matcrial was prepared in $100 \mathrm{ml}$ of aqueous suspension (each $\mathrm{ml}$ of the suspension contained the extract of $1 \mathrm{gm}$ of Khat lcaves). The procedure of extraction was performed in the Pest Control Research Institute, Ministry of Agriculture.

Twenty-four adult virgin female albino rats weighing $200-300 \mathrm{gm}$ were housed in wirc cages under controlled environmental conditions. One adult male rat was introduced into a cage with two females and remained there overnight. Vaginal smears were taken in the next morning. Pregnancy was determined by the presence of sperms in the smcar, this day was considercd to be the first day of gestation. The pregnant rats were divided into four groups (one control and three experimental), each of six rats. Each rat of the control group was injected intraperitoneally with saline daily. Each rat of the three experimental groups was injected intrapcritoneally with daily doses of the Khat extract starting from the first day of pregnancy with one day rest every five days till the $19^{\text {th }}$ day of pregnancy. Each dose consisted of $0.2 \mathrm{ml}$ for the rals of the first group, $0.4 \mathrm{ml}$ for the rats of the second group and $0.8 \mathrm{ml}$ for the rats of the third group containing the extract of $0.2,0.4$ and $0.8 \mathrm{gm}$ of Khat 
leaves respectively. According to Paget and Barnes (1964) interspecies conversion scheme, these doses correspond to the chewing of 12,24 and $50 \mathrm{gm}$ of Khat leaves by an adult $70 \mathrm{~kg}$ man. This dose is within the range of the dose usually consumed by chronic Khat chewers mentioned by Kassie et al. (2001). On the $20^{\text {th }}$ day of gestation, all the pregnant rats were killed by an overdose of elher to prevent the mothers from devouring any malformed offspring.

The abdominal wall of each mother was opened and the full extent of both uterinc horns was exposed. The fetal positions within the uterine horns as well as the number of the live and dead fetuses. detected by movements of the living fetuses following a gentle pressure, were recorded. A careful count was made for the metrial glands, which are yellowish nodules found along the mesometrial margin of the uterine horns, as they mark the implantation sites. Thus, the metrial glands unoccupied by living or recently dead fetuses represented the number of prior resorptions (Wilson, 1965). The total embryolethality (including the number of embryonic resorptions and the number of fetal deaths) as well as the proportion (percentage) of embryolethality to total number of implantations were calculated for each group as follows :

Total embryolethality $=$ Number of embryonic resorptions + Number of fetal deaths

Total embryolethality $\%=$ (Total embryolethality / total number of implantations) $\mathrm{X} 100$

The litter size-defined as the mean number of living fetuses per dam- was also calculated for each group as follows :

Litter size $=$ Total number of living feluses in cach group $/$ number of pregnant rats in the same group.

These parameters were used to estimate the viability of the embryos of rats treated with Khat extract.

Then, the uterine horns werc excised along the antimesometrial border to reveal the fetuses which were gently removed from the uterus. Fetal weight and crownrump length were measured in all living fetuses and the mean values and standard deviations in each group were calculated. About $1 / 3$ of the fetuses were fixed in Bouin's solution. These feluses will be used in a parallel study. About $2 / 3$ of the fetuses were tixed in $95 \%$ ethyl alcohol, then cleared in a solution of $1 \% \mathrm{KOH}$ till the bones became clearly visible through the surrounding tissues. Then, they were transferred to a fresh solution of $1 \% \mathrm{KOH}$ to which alizarin red stain was added (Dawson, 1926) then they were successively transferred to 30\%, 50\% and 70\% 
glycerin solutions and stored in pure glycerin. Thorough examination of the skcletal system was done under a dissecting microscope to evaluate the pattern of ossification of the different bones and to detect any anatomical abnormalities.

Examination included the bones of the axial skeleton (the sternum, ribs, centra of cervical, thoracic, lumbar, sacral and caudal vertebrae and the skull bones) as well as the bones of the appendicular skeleton (the clavicle, scapula, humerus, radius, ulna and metacarpals in the forelimb and the coxal bone, femur, tibia, fibula and metatarsals in the hind limb). Ossification was scored as being either complete, incomplete or absent. Incomplete ossification could be identificd when the center was either small or faintly stained (Kimmel et al., 1982).

For statistical analysis, the centers of ossification (either complete or incomplete) of the sternum, the vertebral centra, the carpus and the tarsus of all fetuses of cach group were counted. Also, the total number of only complete ossific centers in each group was rccorded and expressed as percentage from the total number of centers. Mean and standard deviation values for the number of complete ossific centers - being an index for proper ossification - were calculated.

Number of complete ossific centers $\%=$ (Total number of complete ossific. centers / total number of ossific centers) $\times 100$

Mean complete ossific centers = total number of complete ossific centers in each group / Number of fetuses in each group.

Data concerning embryonic viability (embryolethality and litter size), fetal growth (fetal weight and crown-rump length) and ossification of each of the sternum, vertebral centra, carpus and metacarpus were tabulated and subjected to one way analysis of variance (ANOVA) test. When the ANOVA test was significant, Duncan's multiple range test was performed to show the statistical significance among different groups (F-ratio). Chi square test was used to compare the observed proportions. The Statistical Package for the Social Sciences (SPSS) version 7.5 was used in data analysis.

\section{RESULTS}

\section{Embryonic viability :}

The rates of both embryonic resorption and fetal mortality were increased parallel with the increase in the dose of the injected khat extract (Table 1). The total embryolethality in the control group was four embryos (6.06\%), while in 
the experimental groups, it was six embryos $(9.68 \%)$ in the second group, $13 \mathrm{em}$ bryos $(20 \%)$ in the third group and 21 cmbryos $(33.87 \%)$ in the fourth group. As a result, the litter size - defined as the average number of live fetuses per dam - was statistically significantly decreased in the third group and very highly significantly decreased in the fourth group as compared to the control group.

\section{Fetal growth :}

Fetal growth was evaluated in the present study by measuring the fetal weight and crown-rump length. The data are shown in table (2). It was observed that these parameters were steadily reduced in all treated groups in a dose-dependent manner. The reduction in the mean fetal weight was statistically very highly significant in both the third and fourth groups while the decrease in the mean crown-rump length was significant in the second group, highly significant in the third group and very highly significant in the fourth group. Figure (1) shows the relative decrease in fetal size in different experimental groups.

\section{Evaluation of the skeleton :}

\section{Sternum :}

The total number of sternal ossific centers (either complete or incomplete) that were detected in the 20 - day rat fetuses in each of the different groups is shown in (Table 3). (Fig. 2) shows patterns of ossification of the sternum in fetuses of different groups. (Table 3) also shows the total number of complete ossific centers in each group. Sternal ossific centers were reported as incomplete when they were faintly stained, small or bipartite (Fig. 2 - b). There was a statistically highly significant reduction in the total number of complete ossific centers of the sterna of the fetuses of the second group. while this reduction was very highly significant in the third and fourth groups as compared to the control group. On the other hand, the number of fetuses in each group having no or one sternal ossific center - as shown in table (3) - was recorded (Figs. 2 - d, 2 - e, 2 - f). This type of abnormality was observed in $19.45 \%$ of the fetuses of the third group and its incidence was very high in the fetuses of the fourth group $(100 \%)$.

\section{Ribs :}

Thirteen pairs of ribs were completely ossified in all fetuses of the control and second groups (Fig. 3 - a). Missed ribs were noticed in three $(8.33 \%$ ) of the fetuses of the third group and in five (17.86\%) of the fetuses of the fourth group (Fig. 3 - b). 
Ribs arranged into groups separated from each other (Fig. 3 - c) was observed in one fetus $(3.57 \%)$ of the fourth group while in another fetus (3.57\%) of this group all ribs were short (incompletely ossified) (Fig. 3 - d).

\section{Vertebral column :}

The total number of ossific centers and the number of complcte ossific centers of the centra of the vertebrae in the different regions of the vertebral column are summarized in (Table 4). In the cervical region, ossification of the vertebral centra was not developed in any of the fetuses examined (not included in table 4). Incomplete ossification was reported when the center was small, faintly stained or bipartite. Ossification of the vertebral arches was not included in this study.

Statistical analysis of the data in table (4) revealed that Khat administration to pregnant dams resulted in significant relardation in the development of ossific centers in all regions of the vertebral column as manifested by the reduction of the total number of complete ossific centers. With the highest dose (group four) retardation was statistically very highly significant in all regions. The caudal, sacral and upper thoracic regions were most sensitive to the effect of Khat as retardation of ossification in these regions was statistically significant even in the first group (receiving the lowest dose of Khat). (Fig. 3 - d) shows absent ossification of the centra of upper thoracic and bipartite centra of lower thoracic vertebrae in a fetus of the third group. (Figs. 4 - a, 4 - b) show the pattcrn of ossification in the lumbar, sacral and caudal vertebrae in control fetuses. (Figs. 4 - c, 4 - e) show absent caudal and sacral centra together with incomplete lumbar centra in two fetuses of the third and fourth groups respectively. Also, severe deformity of the vertebral column was observed in three fetuses $(10.7 \%$ ) of the fourth group (Figs. $3-\mathrm{c}, 3-\mathrm{f}$ ).

\section{Skull bones:}

Nine bones of the skull were examined in each fetus ( 2 frontal, 2 parietal, 1 interparietal, 1 supraoccipital, 2 exoccipital, 1 mandible). The other skull bones were not included in this study. Complete ossification of all skull bones was observed in all groups except for the supraoccipital and the interparietal bones. The supraoccipital bone was the most sensitive bone to maternal Khat administration. Complete ossification of the supraoccipital bone was observed in all the fetuses of the control and the second groups and in 32 (88.88\%) and $13(46.42 \%)$ fetuses of the third and fourth groups respectively. The patterns of ossification of the supraoccipital bone (complete, delayed or absent) in different groups are shown in (Fig. 5). The 
interparietal bone was less frequently affected as it showed delayed or absent ossification in only three fetuses (10.7\%) of the fourth group (Figs. 5 - c. 5 - f).

\section{Bones of the fore - and hind limbs :}

The long bones of the fore and hind limbs (humerus, radius, ulna, femur, tibia and fibula) as well as the scapula and clavicle were completely ossified in all fetuses examined.

Centers of ossification of the coxal bone (iliac and ischial) were not affected in any of the fetuses of the control and second groups. The pubic center was not included in this study. The center of ossification of the ilium was incomplete (Fig. 4 - d) or absent (Figs. $4-\mathrm{e}, 4-\mathrm{f}$ ) in two fetuses $(5.55 \%)$ of the third group an in five fetuses $(17.85 \%)$ of the fourth group. The center of ossitication of the ischium was absent (Figs. 4 - c, 4 - d, 4 - e, $4-1$ ) in four fetuses (11.11\%) of the third group and in eight fetuses (28.57\%) of the fourth group.

As regards bones of the paws and feet, ossification centers at that stage of development were detected only in the middle three metacarpals of most of the fetuses of the control group (Figs. 6 - a, 6 - d). The total numbers of ossific centers as well as the percentage and mean of complete ossific centers of metacarpal and metatarsal bones in different groups are shown in (Tables 5 and 6 ) respectively. Highly significant decrease in these percentages was observed in groups receiving high doses of Khat extract as compared to the control group. Moreover, a consistent increase in the number of fetuses having no or one ossific centers in metacarpus and metatarsus - as shown in (Tables 5 and 6) - was observed in parallel with the increase in the dose of Khat administration. (Figs. $6-\mathrm{b}, 6-\mathrm{c}$ ) show incomplete ossification of the metacarpal centers in a fetus of the fourth group and absence of these centers in another fetus of this group. (Figs. 6- e, 6- f) show absent metatarsal centers in two fetuses of the fourth group. 
Table 1 : Effect of maternal Khat administration on embryonic viability.

\begin{tabular}{|c|c|c|c|c|c|c|c|c|}
\hline Group & $\begin{array}{l}\text { Number of } \\
\text { pregnant rats }\end{array}$ & $\begin{array}{c}\text { Total } \\
\text { implantatlons }\end{array}$ & $\begin{array}{l}\text { Embryonic } \\
\text { resorptions }\end{array}$ & $\begin{array}{l}\text { Fetal } \\
\text { deaths }\end{array}$ & $\begin{array}{l}\text { Embry } \\
\text { Total }\end{array}$ & $\underset{\%}{\text { aality }}{ }^{\dagger}$ & $\begin{array}{l}\text { Living } \\
\text { fetuses }\end{array}$ & $\begin{array}{c}\text { Litter size } \\
(\mathbf{M} \pm \mathbf{S D})\end{array}$ \\
\hline $\begin{array}{c}\text { I } \\
\text { (control) }\end{array}$ & 6 & 66 & 3 & 1 & 4 & 6.06 & 62 & $10.3 \pm 1.67$ \\
\hline $\begin{array}{c}\text { II } \\
(0.2 \mathrm{gm})\end{array}$ & 6 & 62 & 4 & 2 & 6 & 9.68 & 56 & $9.3 \pm 1.21$ \\
\hline $\begin{array}{c}\text { III } \\
(0.4 \mathrm{gm}) \\
\end{array}$ & 6 & 65 & 8 & 5 & 13 & 20 & 52 & $\begin{array}{c}8.6 \pm 1.34 \\
*\end{array}$ \\
\hline \multirow[t]{2}{*}{$\begin{array}{c}\mathrm{rV} \\
(0.8 \mathrm{gm}) \\
\end{array}$} & 6 & 62 & 13 & 8 & 21 & 33.87 & 41 & $\begin{array}{c}6.8 \pm 1.08 \\
* * *\end{array}$ \\
\hline & & & & & $\begin{array}{r}++\mathrm{Cl} \\
\mathrm{P}<\end{array}$ & $\begin{array}{l}=16,2 \\
001\end{array}$ & & $\begin{array}{c}+F=7.15 \\
P<0.01\end{array}$ \\
\hline
\end{tabular}

- † Embryolethality = embryonic resorptions + fetal deaths

- ++ Litter size $=$ number of living fetuses $/$ number of pregnant rats

- $M=$ mean $\quad S D=$ standard deviation

- ANOVA test :

- The asterisks indicate statistically significant different means (with respect to the control).

* : significant at $p<0.05 \quad * *$ : highly significant at $p<0.01$

*** : very highly significant at $p<0.001$

-+ : Duncan's multiple range test $; F$ - ratio indicates the overall significance among the means of different experimental groups.

- ++ : Chi square test indicates the overall significance among the proportions of different experimental groups. 
Tahle 2 : Effect of maternal Khat administration on fetal growth.

\begin{tabular}{|c|c|c|}
\hline Group & $\begin{array}{l}\text { Fetal weight (gm) } \\
\qquad(M \pm S D)\end{array}$ & 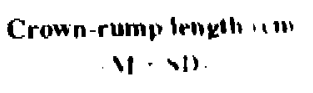 \\
\hline $\begin{array}{c}1 \\
\text { (control) }\end{array}$ & $2.8 \pm 0.21$ & $3.1 \pm 0.15$ \\
\hline $\begin{array}{c}\text { II } \\
(0.2 \mathrm{gm})\end{array}$ & $2.4 \pm 0.13$ & $\begin{array}{c}2.9 \pm 0.1 \\
*\end{array}$ \\
\hline $\begin{array}{c}\text { III } \\
(0.4 \mathrm{gm})\end{array}$ & $\begin{array}{c}1.7 \pm 0.46 \\
* * *\end{array}$ & $\begin{array}{c}2.6 \pm 0.16 \\
* *\end{array}$ \\
\hline $\begin{array}{c}\text { IV } \\
(0.8 \mathrm{gm})\end{array}$ & $\begin{array}{c}1.3 \pm 0.57 \\
* * *\end{array}$ & $\begin{array}{c}2.4 \pm 0.2 \\
\star * *\end{array}$ \\
\hline . & $\begin{array}{c}+F=19.98 \\
P<0.001\end{array}$ & $\begin{array}{c}+F=16.11 \\
P<0.001\end{array}$ \\
\hline
\end{tabular}

- $M=$ mean $\quad S D=$ standard deviation

- ANOVA test :

- The asterisks indicate statistically significant different means (with respect to the control).

- * : significant at $\mathrm{p}<0.05 \quad * *$ : highly significant at $\mathrm{p}<0.01$

*** : very highly significant at $\mathrm{p}<0.001$

- + : Duncan's multiple range test : F - ratio indicates the overall significance among the means of different experimental groups. 
Table 3 : Effect of maternal Khat administration on sternal ossification of 20 day fetuses.

\begin{tabular}{|c|c|c|c|c|c|c|c|}
\hline Group & $\begin{array}{l}\text { No. of } \\
\text { fetusess }\end{array}$ & $\begin{array}{l}\text { Total no. } \\
\text { of centers }\end{array}$ & \multicolumn{3}{|c|}{$\begin{array}{l}\text { No. of complete centers } \\
\text { Total } \% \quad M \pm S D\end{array}$} & \multicolumn{2}{|c|}{$\begin{array}{l}\text { No. of fetuses having 0-1 centers } \\
\text { Total }\end{array}$} \\
\hline $\begin{array}{c}\text { I } \\
\text { (control) }\end{array}$ & 44 & 214 & 192 & 89.72 & $4.36 \pm 1.38$ & 0 & 0 \\
\hline $\begin{array}{c}\text { II } \\
(0.2 \mathrm{gm})\end{array}$ & 38 & 140 & 101 & 72.14 & $\begin{array}{c}2.65 \pm 1.27 \\
* *\end{array}$ & 0 & 0 \\
\hline $\begin{array}{c}\text { III } \\
(0.4 \mathrm{gm})\end{array}$ & 36 & 80 & 38 & 47.5 & $\begin{array}{c}1.05 \pm 0.11 \\
* * *\end{array}$ & 7 & 19.45 \\
\hline \multirow[t]{2}{*}{$\begin{array}{c}\text { IV } \\
(0.8 \mathrm{gm})\end{array}$} & 28 & 5 & 0 & 0 & $\begin{array}{c}0.0 \pm 0.0 \\
* * * *\end{array}$ & 28 & 100 \\
\hline & & & & & $\begin{aligned}+F & =124.9 \\
P & <0.001\end{aligned}$ & & $\begin{array}{l}2=60.2 \\
0.001\end{array}$ \\
\hline
\end{tabular}

- $M=$ mean $\quad S D=$ standard deviation

- ANOVA test :

- The asterisks indicate statistically significant different means (with respect to the control).

- * : significant at $\mathrm{p}<0.05 \quad * *$ : highly significant at $\mathrm{p}<0.01$

**** : very highly significant at $\mathrm{p}<0.001$

-+ : Duncan's multiple range test :F - ratio indicatcs the overall significance among the means of different experimental groups.

- +t : Chi square test indicates the overall significance among the proportions of different experimental groups. 
Table 4 : Effect of maternal Khat administration on ossification of vertebral centra of 20-day fefuses.

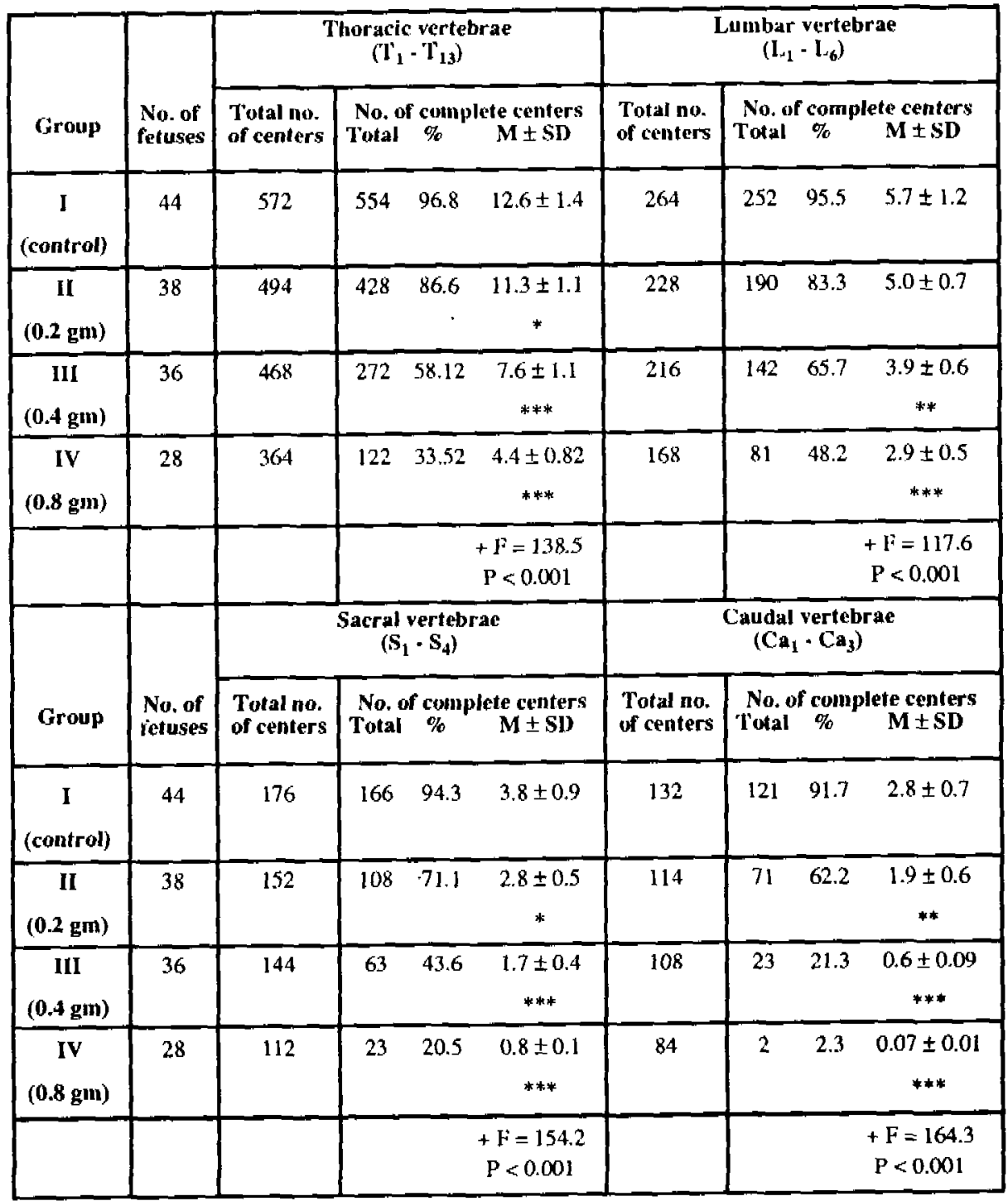

- $\mathrm{M}=$ mean $\quad \mathrm{SD}=$ standard deviation

- ANOVA test :

- The asterisks indicate statistically significant different means (with respect to the control).

- * : significant at $\mathrm{p}<0.05 \quad * *$ : highly significant at $\mathrm{p}<0.01$

***: very highly significant at $p<0.001$

- + : Duncan's multiple range test : $F$ - ratio indicates the overall significance among the means of different experimental groups. 
Table 5 : Effect of maternal Khat administration on ossification of metacarpal bones of 20-day fetuses.

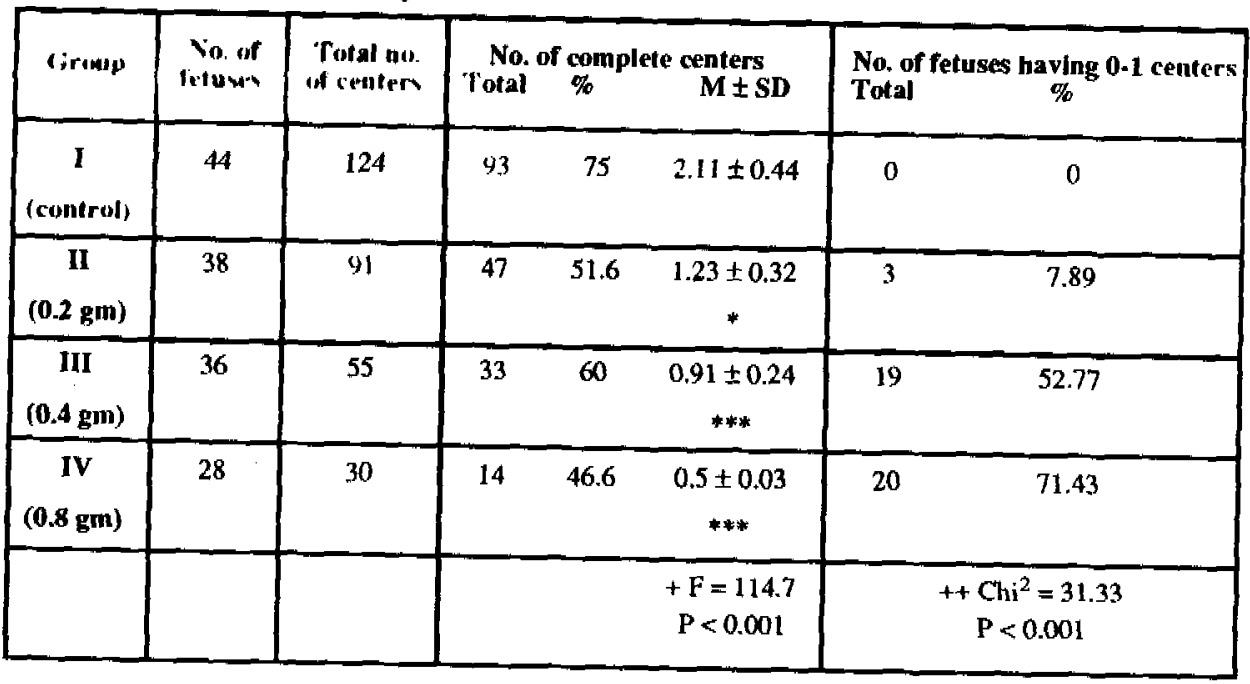

- $M=$ mean $\quad S D=$ standard deviation

- ANOVA test :

- The asterisks indicate statistically significant different means (with respect to the control).

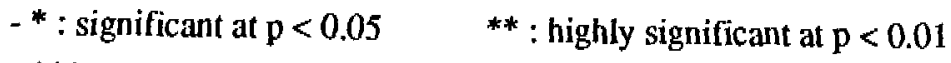

*** : very highly significant at $p<0.001$

- + : Duncan's multiple range test : $F$ - ratio indicates the overall significance among the means of different experimental groups.

- ++ : Chi square test indicates the overall significance among the proportions of dif + ferent experimcntal groups.

- N.B. : The results represent one side only as both sides were identical. 
Tible 6 : Fffect of maternal Khat administration on ossification of metatarsal bones of 20-day fetuses.

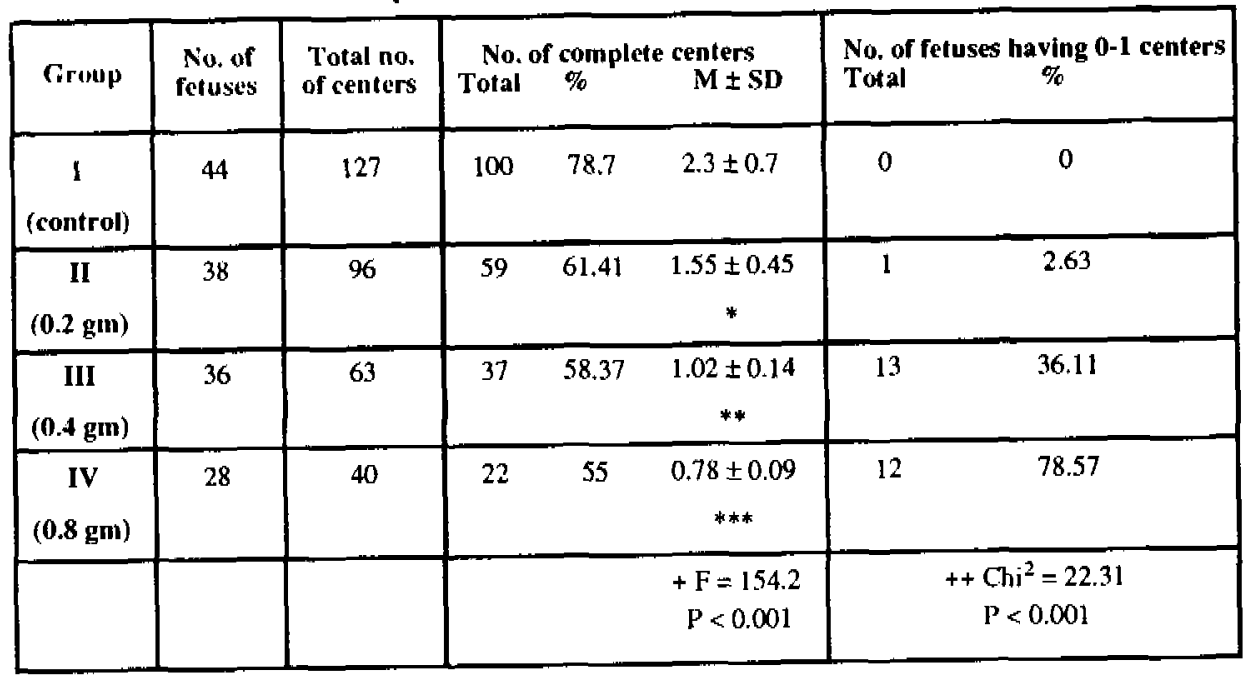

- $\mathrm{M}=$ mean $\quad \mathrm{SD}=$ standard deviation

- ANOVA test :

- The asterisks indicate statistically significant different means (with respect to the control).

_ * : significant at $\mathrm{p}<0.05 \quad * *$ : highly significant at $\mathrm{p}<0.01$

**** : very highly significant at $p<0.001$

- + : Duncan's multiple range test : F - ratio indicates the ovcrall significance among the means of different experimental groups.

- ++ : Chi square test indicates the overall significance among the proportions of different experimental groups.

- N.B. : The results represent one side only as both sides were identical. 


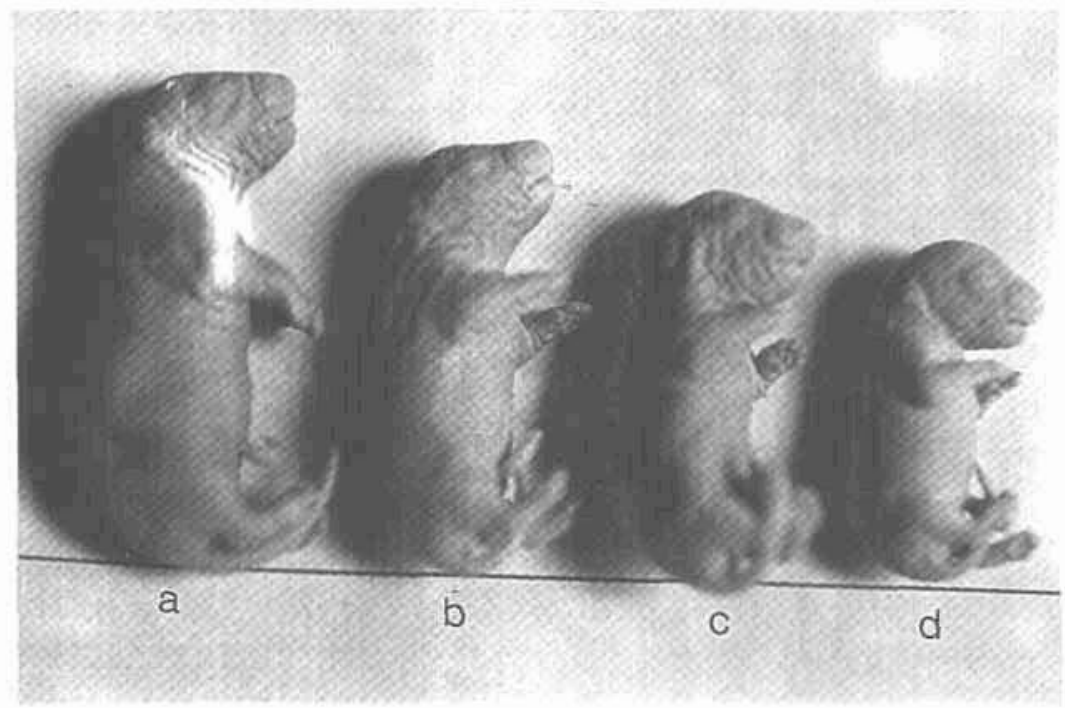

Fig. (1) : Lateral view of four fetuses (fixed in Bouin's solution) showing the difference in size between fetuses of the control (a), second (b), third (c) and fourth (d) groups. 

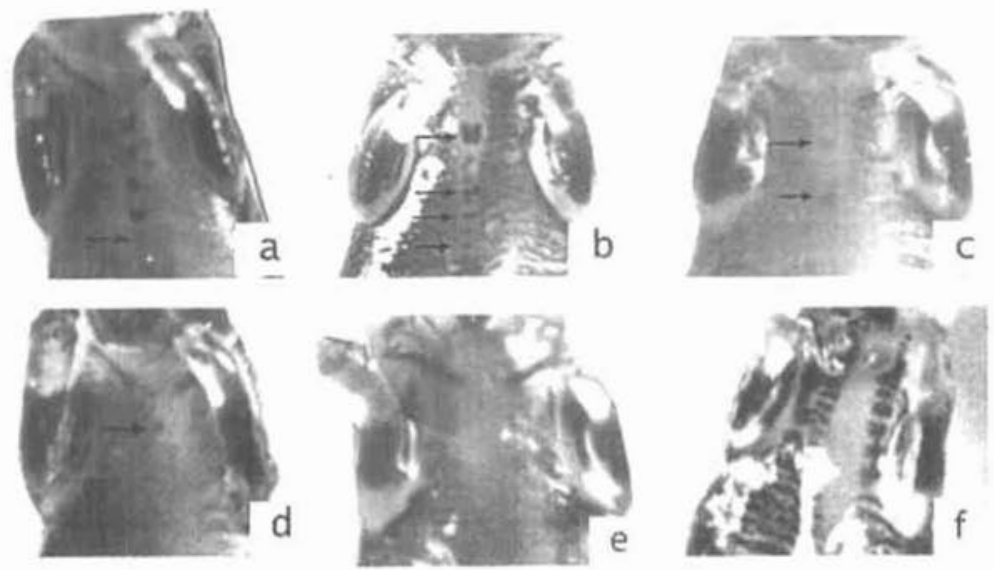

Fig. (2) : Ventral views of the thoracic regions of fetuses of different groups showing stemal ossification (Alizarin red):

(a) Fetus of the control group with four complete centers and one incomplete center (arrow).

(b) Fetus of the $2^{\text {nd }}$ group (receiving the extract of $0.2 \mathrm{gm}$ of Khat leaves) with 4 bipartite ossific centers (arrows).

(c) Fetus of the $3^{\text {rd }}$ group (receiving the extract of $0.4 \mathrm{gm}$ of Khat leaves) with 2 incomplete centers (arrows).

(d) Fetus of the $4^{\text {th }}$ group (receiving the extract of $0.8 \mathrm{gm}$ of Khat leaves) with one incomplete center (arrow).

(e, f) Fetus of the $4^{\text {th }}$ group (receiving the extract of $0.8 \mathrm{gm}$ of Khat leaves) with absence of all stemal ossific centers. 

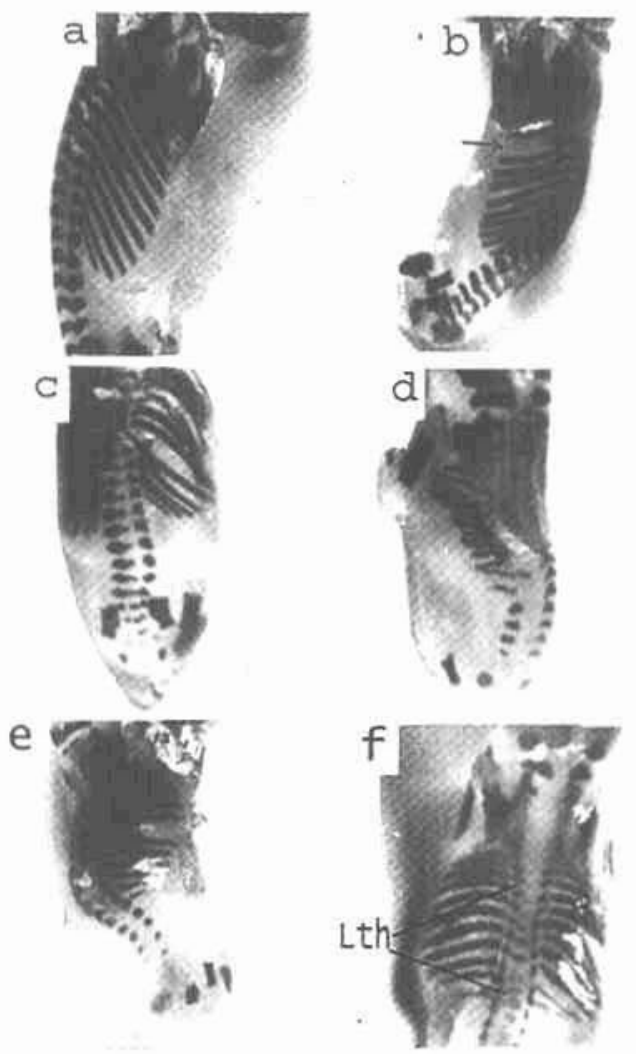

Fig. (3) : Lateral and dorsal views of the middle regions of fetuses of different groups showing ossification of the ribs and thoracic vertebrae (Alizarin red) :

(a) Fetus of the control group showing ribs of the right side.

(b) Fetus of the $3^{\text {rd }}$ (group receiving the extract of $0.4 \mathrm{gm}$ of Khat leaves) with missing left $4^{\text {th }}$ rib (arrow).

(c) Fetus of the $4^{\text {th }}$ group (receiving the extract of $0.8 \mathrm{gm}$ of Khat leaves) with ribs arranged into groups separated from each other.

(d) Fetus of the $4^{\text {th }}$ group (receiving the extract of $0.8 \mathrm{gm}$ of Khat leaves) with incomplete ossification of all ribs and severe defomity of the vertebral column. Note the absence of ossification of the centra of all vertebrae.

(e) Fetus of the $4^{\text {th }}$ group (receiving the extract of $0.8 \mathrm{gm}$ of Khat leaves) with severe deformity of the vertebral column. Note the absence of caudal, sacral and lumbar centra.

(f) Fetus of the $3^{\text {rd }}$ group (receiving the extract of $0.4 \mathrm{gm}$ of Khat leaves) with absent upper thoracic and bipartite lower thoracic centra (Lth). 

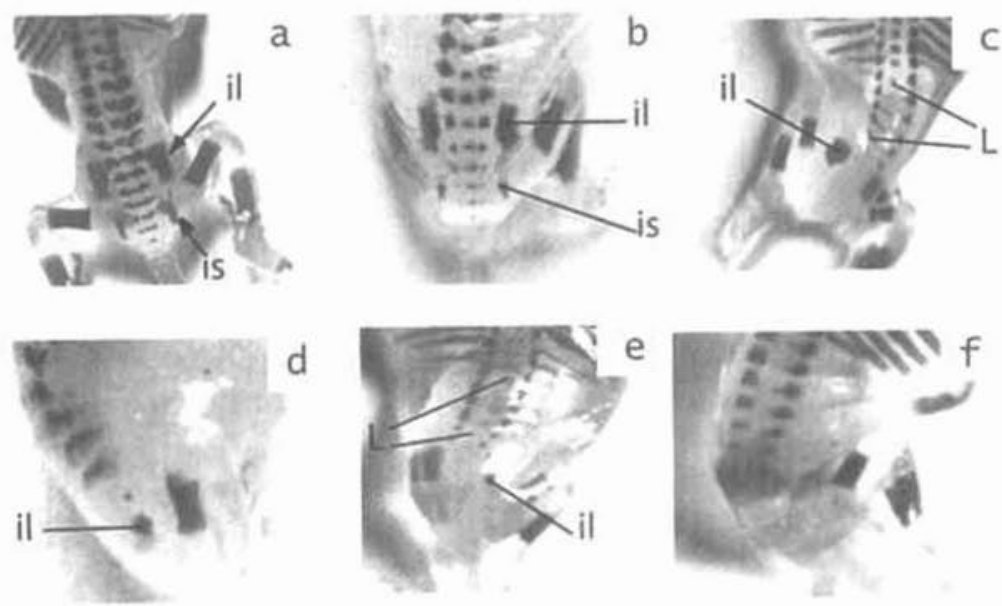

Fig. (4) : Dorsal and lateral views of the caudal regions of fetuses of different groups showing the ossification of the centra of the lower vertebrae and coxal bone (Alizarin red) :

$(a, b)$ Fetuses of the control group Centers of the ilium (il) and ischium (is) are observed. Note the centers of the centra of the lumbar, sacral and caudal vertebrae.

(c) Fetus of the $3^{\text {rd }}$ group (receiving the extract of $0.4 \mathrm{gm}$ of Khat leaves) with absent caudal and sacral centra and incomplete lumbar centra (L). The iliac center (il) is complete while the ischial center is absent.

(d) Fetus of the $3^{\text {rd }}$ group (receiving the extract of $0.4 \mathrm{gm}$ of Khat leaves) with incomplete iliac center (il) and absent ischial center.

(e) Fetus of the $4^{\text {th }}$ group (receiving the extract of $0.8 \mathrm{gm}$ of Khat leaves) with incomplete iliac center (il) and absent ischial center. Absence of caudal and sacral centra together with incomplete ossification of the lumbar centra (L) is also observed.

(f) Fetus of the $4^{\text {th }}$ group (receiving the extract of $0.8 \mathrm{gm}$ of Khat leaves) with absence of both iliac and ischial centers. 

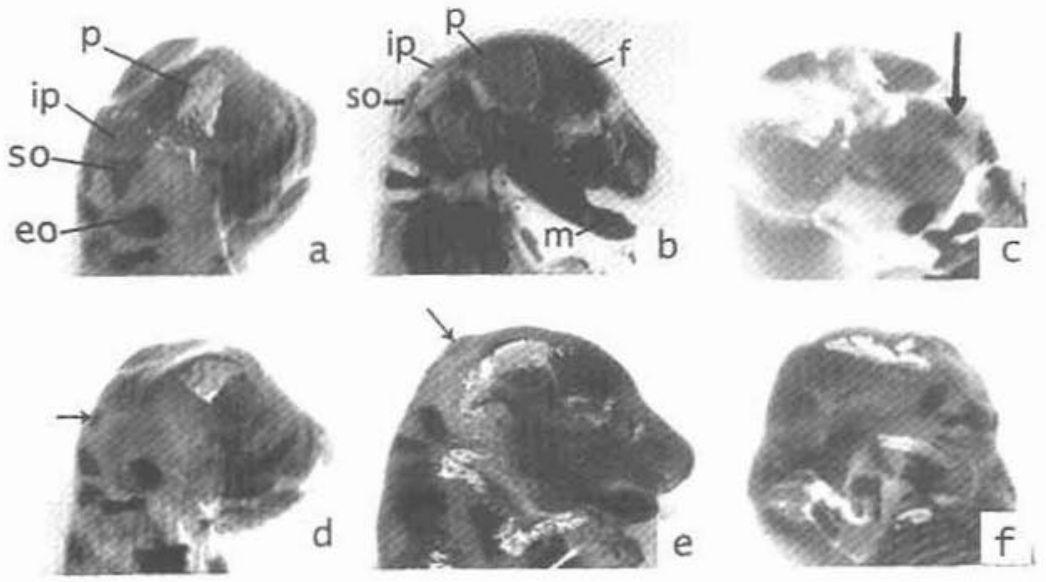

Fig. (5) : Dersal and lateral views of the cephalic regions of fetuses of different groups showing ossification of some skull bones (Alizarin red) :

(a) Fetus of the control group showing ossification of parietal (p), interparietal (ip), supraoccipital (so) and exoccipital (eo) bones.

(b) Fetus of the control group showing ossification of mandible ( $\mathrm{m})$, frontal (f), parietal (p), interparietal (ip), supraoccipital (so) bones.

(c, d) Fetuses of the $3^{\text {rd }}$ and $4^{\text {th }}$ groups (receiving the extract of 0.4 and $0.8 \mathrm{gm}$ of Khat leaves respectively) with incomplete ossification of the supraoccipital bone (arrow).

(e) Fetus of the $4^{\text {th }}$ group (receiving the extract of $0.8 \mathrm{gm}$ of Khat leaves) with absent ossification of the supraoccipital bone and incomplete ossification of the interparietal bone (arrow).

(f) Fetus of the $4^{\text {th }}$ group (receiving the extract of $0.8 \mathrm{gm}$ of Khat leaves) with absent ossification of hoth the supraoccipital and interparietal bones. 

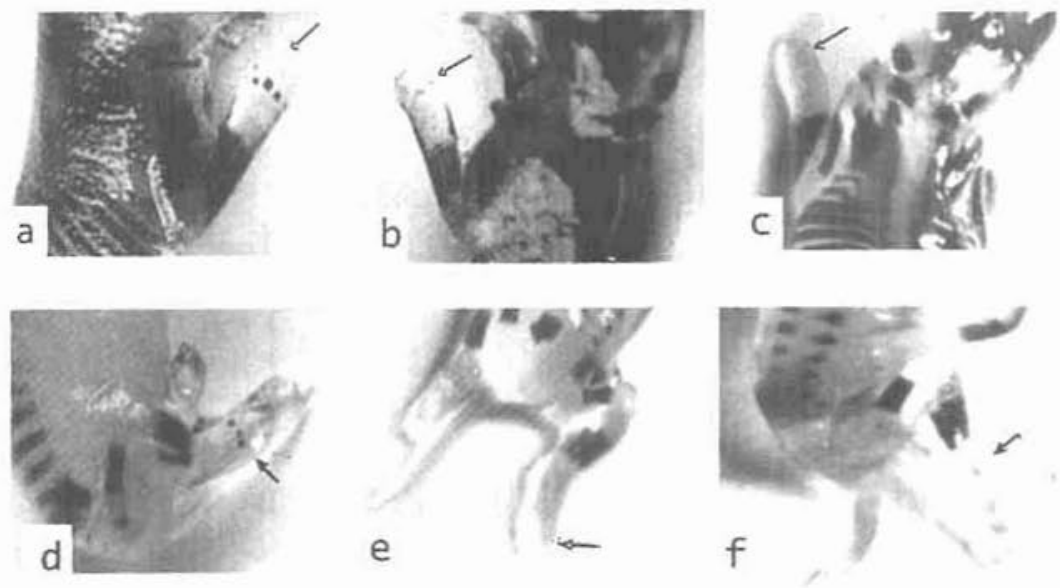

Fig. (6) : Different views of the fore - (a, b and c) and hind - (d, e and f) limbs of fetuses of different groups showing ossific centers in metacarpus and metatarsus (Alizarin red) :

(a) Fetus of the control group showing 3 ossific centers in the metacarpus (arrow).

(b) Fetus of the $3^{\text {rd }}$ groups (receiving the extract of $0.4 \mathrm{gm}$ of Khat leaves) with incomplete ossification of 2 metacamal bones (arrow).

(c) Fetus of the $4^{\text {th }}$ group (receiving the extract of $0.8 \mathrm{gm}$ of Khat leaves) with absent ossification of all metacarpals (arrow).

(d) Fetus of the control group showing 3 ossific centers in the metatarsus (arrow).

(e, f) Fetuses of the $4^{\text {th }}$ group (receiving the extract of $0.8 \mathrm{gm}$ of Khat leaves) with absent ossification of all metatarsals (arrows). 


\section{DISCUSSION}

The toxic cffect of khat on various organs have been described in many reports either in clinical practice (Mekasha, 1983; Soufi et al., 1991; Kassie et al., 2001) or in experimental studies (Al-Ahdal et al., 1988; Islam et al., 1990; AlMeshal et al., 1991; Hanaa et al., 1994; Zaghloul and Nada, 1994). Yet only few reports dealt with its possible effects on the offspring of Khat chewer mothers. $\mathbf{A b}$ dul Ghani et al. (1987) and Eriksson et al. (1991) observed significant increasc in the incidence of low birth weight babies delivered to mothers who were regular Khat chewers. In the present study, marked dose-dependent growth retardation, detccted by measuring the fetal weight and crown-rump length, was observed in the offspring delivered to pregnant rats injected intraperitoneally with khat extract. The present results are in agrcement with many previous reports which showed that treatment with khat caused fetal growth retardation in experimental animals (Jansson et al., 1988; Islam et aI., 1994; Gamal, 1996).

Eriksson (1991) obscrved no increase in rates of stillbirth among Khat users. However, the present study showed that injection of Khat extract to pregnant rats resulted in a dose-dependent increase in the cmbryolethality (deaths and resorptions) as well as significant reduction of litter size. Abdul Ghani et al. (1987) mentioned that since low birth weight was a well-established risk factor for both perinatal and young infant death, Khat chewing during pregnancy might be one of the factors contributing to infant mortality in communities where Khat was commonly chewed.

Aliverti et al. (1979) and Ariyuki et al. (1982) cstablished a relationship between low body weight and retarded ossification induced by teratogenic agents. They found that the stage of skeletal ossification in rat feluses provided a reliable quantitalive index for evaluating retarded fetal development in addition to conventional somatometric measurements such as body weight and crown-rump length.

A marked teratogenic effect of khat on the development of the skeletal system in rats was obscrved in this study. This effect was manifested either by delayed (incomplete or absent) ossification of some bones or by appearance of skcletal deformities. Reduction of the total number of complete ossific centers after Khat administration to pregnant dams was observed in the stemum, the centra of thoracic, lumbar, sacral and caudal vertebrae, the metacarpal and metatarsal bones. Statistical analysis revealed that this reduction was dose-dependent. Delayed ossification was also observed in the centers of the ilium and ischium. In the skull, the supraoccipital bone was the only bone significantly affected. A consistent tendency of 
these abnormalities was observed in the higher dose group. The delayed ossification was most severe in the sternum and caudal vertebrac as the total number of complete ossific centers was highly significantly reduced in all the treated groups as compared to the control group. Moreover, very scvere retardation of ossification of the sternebrae was observed with high doses of Khat as all the fetuses of the fourth group showed cither no or one ossific center which - when present - were all incomplete. These findings might be explained by the confirmation of Ariyuki et al. (1982) that the ossification of the supraoccipital bone of the skull, the sternebrae, the metacarpus and the metatarsus were most sensitive to fetal growth retardation. Similar observations were reported by Islam et al. (1994) on rat fetuses of Khat treated dams.

Studies reporting malformations which might be caused by Khat administration to pregnant rats are few in literature. Thordstein et al. (1991) concluded that Khat exposure during fetal life had an impact on the ccrebral function during the neonatal period. The visceral examination of rat fetuses of Khat treated dams performed by Islam et al. (1994) revealed many malformations including cleft lip, cleft palate, club foot, microcephaly and hydrocephaly while the skeletal examination revealed malformed premaxilla, maxilla and clavicle, unilateral fused and missing ribs. The skeletal deformitics observed in the prescnt siudy were manifested by missing ribs. ribs arranged into groups scparated from each other and severe deformity of the vertebral column. These malformations werc specially recorded in groups receiving high doses of Khat extract.

Many previous works dealt with the possible mechanism of the teratogenic action of Khat. Al-Meshal (1987) and Tarik et al. (1990) reported that Khat cxtract had a dominant lethal mutagenic effect. Furthermore, a genotoxic effect of Khat was described by Qureshi et al. (1988) as a teratogenic underlying factor of Khat abuse. They reported that Khat administration to mice induced significant chromosomal aberrations viz. Aneuploids, autosomal univalents, univalence of the sex chromosomes with an increase in the frequency of abnormal sperms. This genotoxic effect was confirmed by Kassie et al. (2001) who studied the buccal and bladder mucosa of Khat consumers.

Some authors attribute fetal growth retardation after Khat administration to impaired nutrition of the letus in utero cither due to reduction of placental blood flow (Jansson et al., 1988) or to severe debilitation of the mother as a result of decreased food consumption in response to the amorexigenic effect of Khat (Nencini and Ahmed, 1989). De Hondt et al. (1984) showed that the Khat had a profound inhibitory effect on the cell proliferation and on the DNA, RNA and the total protein 
synthesis. Islam et al. (1990) showed that the symptoms observed in Khat chewers including hyperthermia, anorexia and metabolic changes might, to some extent, be attributed to the thyroid stimulating effect of khatamines, and that this effect might be an additional mechanism of khat teratogenicity. House et al. (1994) claimed that khat disturbed the cellular immune mechanism of cultured cells, and that this disturbance might be an underlying factor for the toxic and teratogenic potentials of khat. Recently Al-Qirim et al. (2002) suggested that Khat administration enhanced free radical concentration through a decrease in the levels of free radical metabolizing enzymes.

In conclusion, the present study demonstrated obviously that besides its high embryolethality and its effect on the fetal growth, khat had a teratogenic effect on the development of the skelctal system in rats. However, this toxic effect was related to the amount of Khat intake. This finding necessitates more detailed chemical and ultrastructural experiments in order to evaluate the dynamic events occurring in response to the khat administration. Morcover, postnatal study is needed to determine whether the missing centers will appear in later stages of development.

\section{SUMMARY}

Khat (Catha Edulis) is a plant that grows in East Africa and Southern Arabia and has a central stimulant effect in man similar to amphetamine. A large number of pcople in such areas are used to chew Khat leaves because of its pleasurable and stimulating effects. Many studies revealed that Khat had a toxic effect on various organs as well as a teratogenic cffect. The present work focused on the effect of khat administration during pregnancy on the embryonic viability, fetal growth and the development of the skeletal system in the albino rat.

Twenty-four adult virgin female albino rats weighing $200-300 \mathrm{gm}$ were used in this stuy. The pregnant rats were divided into four groups (one control and three experimental). Each rat of the experimental groups was injected intraperitoneally with 15 daily oses of aqueous suspension of Khat extract strating from the first day of pregnancy with one day rest every five days. Each dose consisted of the extract $0.2 \mathrm{gm}, 0.4 \mathrm{gm}$ and $0.8 \mathrm{gm}$ of Khat extract for the first, second and third experimental groups respectively. Fetuses were collected by caesarian section at the $20^{\text {th }}$ day of gestation. Bones were stained by alizarin red.

An evident dose-dependent embryolethality and fetal growth retardation were observed in the experimental rats. The present work revealed that there was a 
marked leratogenic effect of khat on the development of the skeleton. This effect was manifested either by incomplete or absent ossification of some bones or by the ocurrence of skeletal deformities. Statistical analysis showed that the most sensitive ossific centers were those of the stemum, the centra of the upper thoracic and caudal vertebrac. Other bones affected included the lower thoracic, lumbar and sacral centra, the ribs, the ilium the ischium, the metacarpals, the metatarsals and the supraoccipital bone of the skull. These effects were marked by the increase in the dose of the injected khat extract.

Many cxplanations for the possible teratogenic mechanism of khat have been revicwed.

According to the present results as well as to the other teratogenic effects of khat described in previous works, it is advisable, in spite of the species differences, to avoid khat chewing by the pregnant women.

\section{REFERENCES}

1. Abdul-Ghani, N.; Eriksson, M.; Kristiansson, B. and Qirbi, A. (1987) : The inlluence of Khat chewing on birth weight in full term infants. Sco. Sci. Med., 24 (7) : $625-627$.

2. Al-Ahdal, M.N.; McGarry, T.J. and Hănnan, M.A. (1988) : Cytotoxicity of khat extract on cultured mammalian cells : Effects on macromolecule biosynthesis. Mutat. Res., 204 (2) : 317 - 322.

3. Aliverti, V.; Bonanomi, L.; Giavini, E.. Leone, V.G. and Mariani, L. (1979): The extent of fetal ossification as an index of delayed development in teratogenic studies on the rat. Teratology, 20 (2) : 273 - 342.

4. Al-Meshal, I.A. (1987) : Mitodepressive effect of (-) - cathinone, from Catha Edulis (Khat), on the merismatic region of Allium Cepa root tips. Toxicon., 25 (4) : 451 - 454.

5. Al-Meshal, I.A.; Qureshi, S.; Ageel, A.M. and Tarik, M. (1991) : The toxicity of Catha Edulis (Khat) in mice. J. Subst. Abuse, 3 (1) : 107 - 115.

6. Al-Qirim, T.M.; Shahwan, M.; Zaidi, K.R.; Uddin, Q. and Banu, N. (2002) : Effect of khat, its constituents and restraint stress on free radical metabolism of rats. J. Ethnopharmacol., 83 (3) : 245 - 250.

7. Ariyuki, F.; Ishihara, H.; Higaki, K. and Yasuda, M. (1982) : A study of fetal growth retardation in teratological tests : relationship between body weight and ossification of the skeleton in rat fetuses. Tcratology, 26 (3) : $263-267$. 
8. Brenneisen, R.; Fisch, H.U.; Koelbing, U.; Geisshusler, S. and Kalix, P. (1990) : Amphetamine-like effects in humans of the khat alkaloid cathinone. $\mathrm{Br}$. J. Clin. Pharmacol., 30 (6) : 825 - 828 .

9. Calcagnetti, D.J. and Schechter, M.D. (1992) : The increase in locomotor activity after intracerebral administration of cathinone. Brain Research Bull., 29 (6) : $843-848$.

10. Dawson, A.B. (1926) : A note on the staining of the skeleton of cleared specimens with alizarin red stain. Stain Tech., $1: 123-127$.

11. De Hondt, H.A.; Fahmy, A.M. and Abd El-Basset, S.A. (1984) : Chromosomal and biochemical studies on the effect of khat extract on laboratory rats. Environ. Mutagen., 6 (6) : 851 - 860 .

12. Eriksson, M.; Ghani, N.A. and Kristiansson, B. (1991) : Khat chewing during pregnancy - effect upon the off - spring and some characteristics of the chewers. East Afr, Med. J., 68 (2) : $106-111$.

13. Gamal, S.A. (1996) : Effect of khat extract (Catha Edulis Forsk) administration on the intrauterine fetal growth in the rat. Egypt. J. Anat., 19 (1) : 251 - 277.

14. Hanaa, A.K.; Somaya, Z.; Sahar, A.A.; Sobhi, A.I, and Ali, D. (1994) : A histological study on the effect of khat on the pituitary, ovary and suprarenal of albino rat. Egypt. J. Anat., 71 (4) : $255-284$.

15. House, R.V; Thomas, P.T. and Bhargava, H.N. (1994) : Comparison of immune functional parameters following in vitro exposure to natural and synthetic amphetamines. Immunopharmacol. Immunotoxicol., $16(1): 1$ - 21 .

16. Islam, N.W.; Al-Shabanah, O.A.; Al-Harbi, M.M. and Al-Gharably, N.M. (1994) : Evaluation of teratogenic potential of khat in rats. Drug Chem. Toxicol,, $17(1): 51-68$.

17. Islam, N.W.; Tarik, M.; El Feraly, F.S. and Al-Meshal, I.A. (1990) : Effect of khatamines and their enantiomers on plasma triiodothyronine and thyroxine levels in normal Wister rats. Am. J. Clin. Med., 18 (1 - 2) : 71 - 76.

18. Jansson, T.; Kristiansson, B. and Qirbi, A. (1988) : Effect of khat on maternal food intake, maternal weight gain and fetal growth in late-pregnant guinea pig. $J$. Ethnopharmacol., 23 (1) : 11 - 17.

19. Kalix, P. (1988) : Khat : A plant with amphetamine effects. J. Subst. Abuse Treat., $5(3)$ : 136 - 139.

20. Kalix, P. (1990) : Pharmacological properties of the stimulant Khat. Phamacol. Ther., 48 (3) : 397 - 416. 
21. Kalix, P. (1991) : The pharmacology of psycho-active alkaloids from ephedra and catha. J. Ethnopharmacol., 32 (1 - 3): 201 - 208.

22. Kalix, P. (1992) : Cathinone, a natural amphetaminc. Pharmacol. Toxicol.. 70 (2) : $77-86$.

23. Kassie, F.; Darroundi, F.; Kundi, M.; Schulte-Hermann, R. and Knasmuller, S. (2001) : Khat (Catha Edulis) causes genotoxic effects in humans. Int. J. Cancer, 92 (3) : 329 - 332.

24. Kimmel, C.A.; Laborde, J.B. and Trammel, C.T. (1982) : Evaluation of canilage and bone formation in fetal skeletons following prenatal insult reveals abnormalities not apparent in alizarin-stained specimens. Teratology, $25: 54 \mathrm{~A}$.

25. Klein, M. (1979) : Analysis of khat constituents by UN lab. Geneva, Switzerland. Toxicol., 40 (1) : 186 - 192.

26. Kristianson, B.; Abdul-Ghani, N.; Eriksson, M.; Carle, M. and Qirbi, A. (1987) : Use of Khat in lactating women : A pilot study on breast-milk secretion. J. Ethnopharmacol., $21: 85 \cdot 89$.

27. Mekasha, A. (1983) : Clinical and pharmacological aspects of khat: The clinical effeci of khat (Catha Edulis Forsk). International Symposium of Khat, 77 - 82.

28. Nencini, P. and Ahmed, A.M. (1989) : Khat consumption : a pharmacological review. Drug Alcohol Depend, 23 (1): 19 - 29.

29. Paget, G.E. and Barnes, J.M. (1964) : Toxicity tests In Evaluation of Drug Activities : Pharmacometrics, Vol I. Ed. by Laurence, R.E. and Bocharch, A.L., Academic press', London, New York, P.P. 135 - 155.

30. Qureshi, S.; Tarik, M.; Parmar, N.S. and Al-Meshal, I.A. (1988) : Cytological effects of khat in somatic and male germ cells of mice. Drug Chem. Toxicol., 11 (2) : 151 - 165 .

31. Saleh, M.; Mekkawy, H. and El-Komy, F. (1988) : Acute effects of Khat extract on the rat encephalogram. J. Ethnopharmacol., 23 (2 - 3) : 291 - 298.

32. Schechter, M.D. (1990) : Dopaminergic nature of acute cathine tolerance. Pharmacol. Biochem. Behav., 36 (4) : 817 - 820 .

33. Soufi, H.E.; Kameswaran, M. and Malatani, T. (1991) : Khat and oral cancer. J. Laryngol. Otol., 105 (8) : 643 - 645.

34. Szendrei, K. (1980) : The chemistry of Khat. Bull. Narc., 32 (3) : 5 - 35.

35. Tarik, M.; Qureshi, S.; Ageel, A.M. and Al-Meshal, L.A. (1990) : The induction of dominant lethal mutations upon chronic administration of khat in albino mice. Toxicol. Lett. $50(2-3): 349-353$. 
36. Thordıtein, M.; Jansson, T. and Kristiansson, B. (1991) : Cerebral function 1) the guinea pig neonate after chronic intrauterine exposure to Khat (Catha Edulis Forsk). Biol. Neonate, 59 (3) : 161 - 170.

37. Wilder, P.; Mathys, K.; Brenneisen, R.; Kalix, P. and Fisch, M.U. (1994) : Pharmat indvnamics and Pharmacokinetics of khat : a controlled study. Clin. Pharmacol. The $55(5): 556-562$.

38. Wilson, J.G. (1965) : Teratology : Principles and Techniques. University of Chicago press, Chicago and London, Chapter 10.

39. Zaghloul, S.S. and Nada, S.A. (1994) : Histological and histochemical studies on the effects of Khat on the thyroid gland of albino rat. Egypt. J. Anat., 17 (3) : $41-61$.

40. Zein, A.Z. (1983) : Chemical and pharmacological aspects of Khat : Polydrug abuse among Ethiopian university students with particular reference to khat (Catha Edulis). International Symposium of Khat, 83 - 89. 


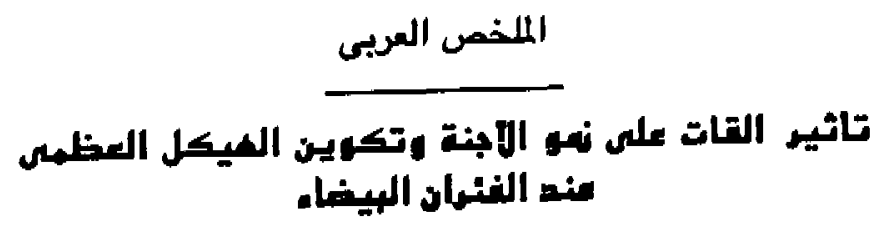

نهلاء علد إباهيم

قسم التشريع - كلية الطب - جامعة التاهرة

ينمو نبات التات فى شرق أفريقيا وجنهب الجزيرة العربية ، ولهذا النبات تاتئير

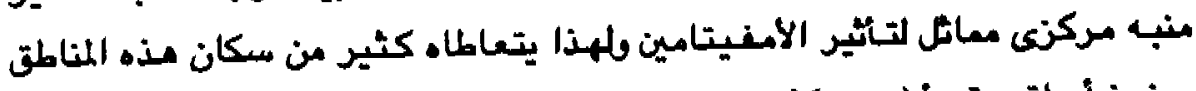

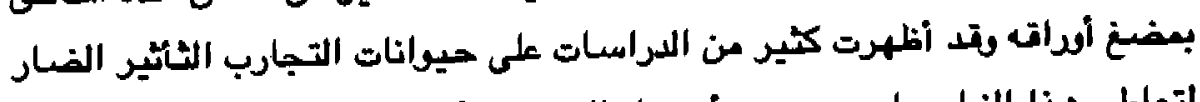

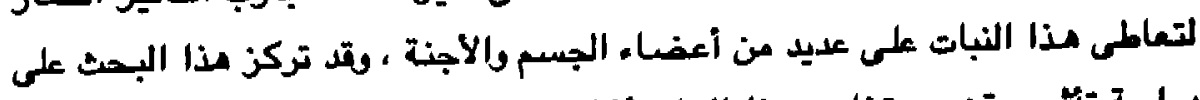

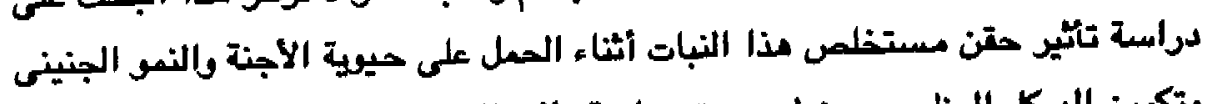

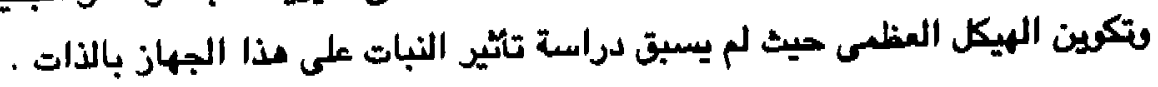

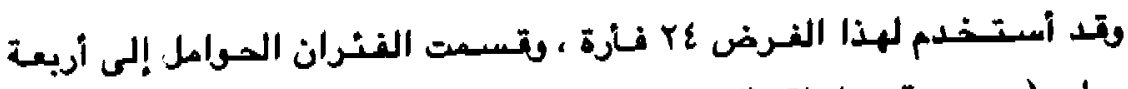

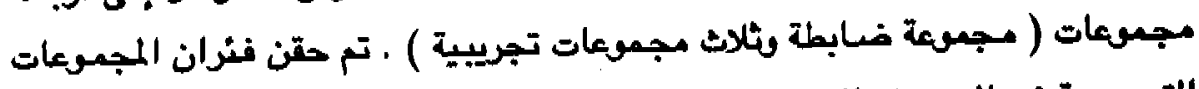

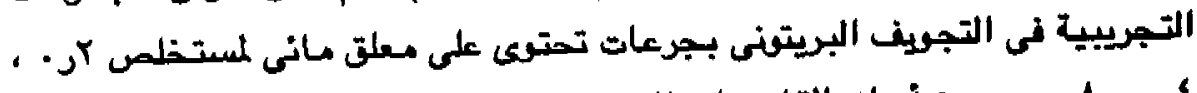

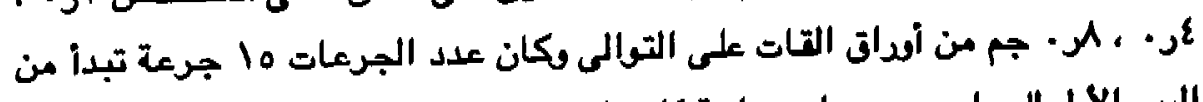

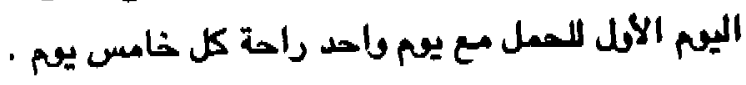

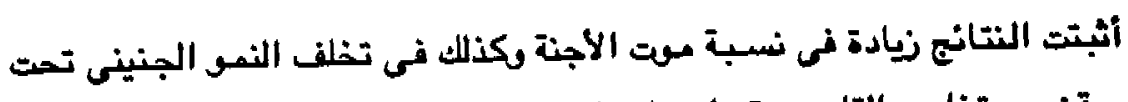

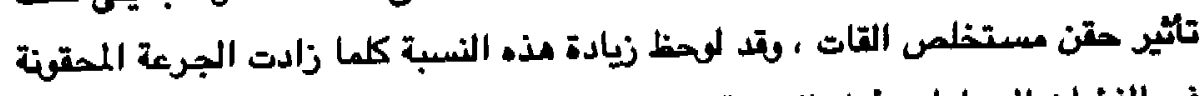

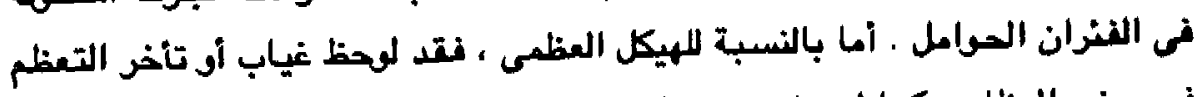

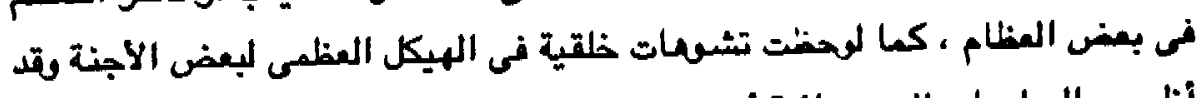

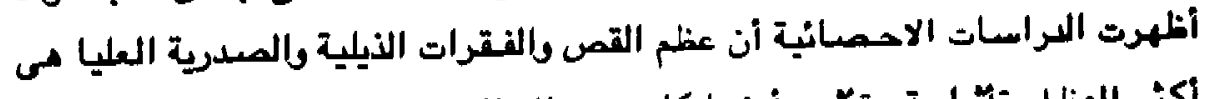

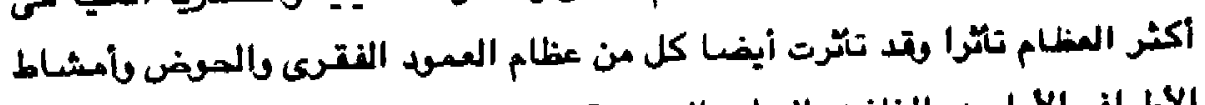

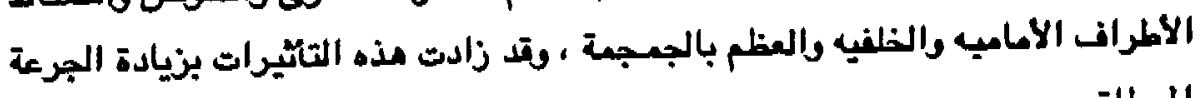
المعطاة . 
رقد تم استعراض الآراء المختفة لكيفية نأثير القات على إحسداث التشـوهات الجنينية .

وبناء على نتائج مذا البعث واستنادا إلى التشوهات الخلقية الآخرى التى يسبيها

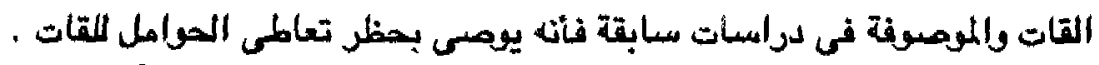

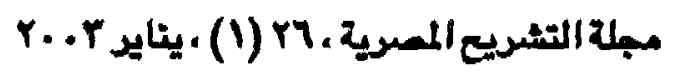

